
Egypt. Acad. J. Biolog. Sci., 13(2):295-303 (2020)

Egyptian Academic Journal of Biological Sciences

A. Entomology

ISSN 1687- 8809

http://eajbsa.journals.ekb.eg/

\title{
Feeding Preferences of Red Pumpkin Beetle, Aulacophora foveicollis Lucas (Chrysomelidae: Coleoptera) on Different Cucurbit Cultivars
}

\author{
Muhammad Hannan Ahmad ${ }^{1}$, Muhammad Afzal ${ }^{1}$, Muhammad Irfan Ullah ${ }^{*}$, Naunain \\ Mehmood $^{2}$, Sajjad Ali ${ }^{3}$, Muhammad Arshad ${ }^{1}$, and Abu Bakar Muhammad Raza ${ }^{1}$ \\ 1-Department of Entomology, University of Sargodha,40100 Sargodha \\ 2-Department of Zoology, University of Sargodha, 40100 Sargodha \\ 3-Department of Entomology, The Islamia University, Bahawalpur \\ Email: muhammad.irfanullah@uos.edu.pk
}

\begin{abstract}
ARTICLE INFO
Article History

Received: $1 / 5 / 2020$

Accepted: 27/6/2020

Keywords:

Red pumpkin beetle, Pumpkin, Cucumber, Bitter gourd, Ridge gourd, Water melon
\end{abstract}

Red pumpkin beetle (RPB) is one of the most notorious insect pest and a serious threat to all cucurbits. Five cultivars of cucurbits, Cucumis sativus L., Momordica charantia L., Luffa acutangula L., Cucurbita pepo L. and Citrullus lanatus (Thunb.) were tested for feeding preferences of RPB for two years. All the cultivars of cucurbits were highly infested in their foliage and flowers resulting in a decline of yield. High RPB infestation was recorded in 2015 compared to 2014. The average population per ten leaves was high in pumpkin and cucumber but low in bitter gourd. Overall data showed that pumpkin was highly preferred cultivar followed by cucumber, watermelon, ridge gourd and bitter gourd. In no choice test, the highest reduction in the leaf area was recorded in pumpkin followed by ridge gourd, cucumber, bitter gourd and water melon. Therefore, appropriate control measure may be taken into consideration as per susceptibility of the host to reduce RPB infestation. Our studies have shown that bitter gourd was the least preferred cultivar, thus, planting bitter gourd as companion crop as borders or in mix cultivation could safeguard other cucurbits.

\section{INTRODUCTION}

Pakistan is an agricultural country where about $65 \%$ of the populationis directly or indirectly dependent on agriculture. Agriculture sector is the main contributor in economy of the country sharing $21 \%$ of GDP (PES, 2016-2017). Farming is the major source of income through production, processing and distribution of agricultural commodities all over the world.

The cucurbit family includes various vegetables like cucumber (Cucumis sativus), muskmelon (Cucumis melo), watermelon (Citrullus lanatus), gourd (Lagenaria siceraria), squash (Cucurbita pepo) and bitter gourd (Momordica charentia). Cucurbits are important vegetable crops grown in summer season (PES, 2016-17). Cucurbits grow best at optimum temperature of $18-30^{\circ} \mathrm{C}$. Cucurbits are nutritionally enriched with essential constituents required for good health and well-being (Rahman, 2003). Squash is a good source of fiber, vitamin $\mathrm{C}$ and potassium. Winter squash is rich in antioxidant, beta-carotene, which in the 
form of vitamin A enhances vision and improves immune system. Vitamin $\mathrm{C}$ is helpful in healing wounds, preventing cell damage and strengthening the immune system (Malik et al., 2011).

A number of insect pests are known to attack cucurbits, including spotted cucumber beetles, striped cucurbit beetle, squash bug and red pumpkin beetle. A. foveicollisis the most serious polyphagous pest of the cucurbits. It causes $35-75 \%$ damage to all cucurbits except bitter gourd at seedling stage. The adult beetle is red, oblong and approximately 6-8 $\mathrm{mm}$ long and lays its eggs at the base of the cucumber stem. A single female can lay 150-300 eggs (Rahaman et al., 2008; Rajak, 2001).

Red pumpkin beetle feeds underside the cotyledonous leaves by biting holes into them. Leaves look like skeleton during severe attack. The severity of infestation is evident from the fact that it attacks cucurbits at all developmental stages specially causing irreversible damage at the initial stages. Immature beetles damage the roots, feeding on the underground parts of the plant, flowers, flower buds and foliage causing considerable losses to newly emerging plants (Mahmood et al., 2010). Heavy infestations are seen during the spring season by generating irregular holes in the leaves and seeds resulting in defoliation of the cucurbit seedlings. Initial damage at early spring season may even result in re-sowing of crops (Dhillon et al., 2005).

Management of this pest demands necessary knowledge host plant interactions of RBP for determining feeding and oviposition preferences. Although, several researches have focused on various aspects related to its density in different crops, yet its feeding preferences have not been explored in detail (Khan et al., 2012; Khursheed et al., 2013).

Application of synthetic pesticides for the management of RPB has many serious environmental concerns. Insecticidal residues can harm the health of consumers. An effective approach could be the use of resistant varieties for protection from pest attack (Karim, 1992; Bhaduri et al., 1990). Different oils including neem oil (Azadirachta indica) are used for the management of red pumpkin beetle. Another management strategy involves employing different seed (Pachyrrhizus erosus and Strychnos nuxvomica) and plant extracts (Annona squamosa, Melia azedarach and Convolvulus microphyllus) for the control of this pest (Osman et al., 2013; Vishwakarma et al., 2011).

Currently, a number of insecticides are being used for the pest management. Different pesticides like larvin, diazinon, permethrin, malathion, monocrotophos, chlorpyriphos and carbaryl are being used for the proper management of the red pumpkin beetle (Osman et al., 2013; Mahmood et al., 2010). Therefore, a comprehensive study was planned for determination of host preference of red pumpkin beetle on various cucurbit cultivars. Furthermore, nutritional characteristics of each cultivar were also assessed to determine if they had any role in modulating feeding preferences of red pumpkin beetle.

\section{MATERIALS AND METHODS}

The experimental area was located at the research area of College of Agriculture, University of Sargodha, Sargodha $\left(32.0737^{\circ} \mathrm{N}, 72.6804^{\circ} \mathrm{E}\right)$.

Power tiller was used for preparation of the experimental field. Prepared field was exposed to sunshine for 7 days prior to next ploughing. Thereafter, the land was ploughed and cross-ploughed to obtain good tilth. Recommended doses of farmyard manure and fertilizer were applied (Rashid, 1993) for cucurbits at the rate of $10000 \mathrm{~kg}$ of farm yard manure while, $69 \mathrm{~kg}$ Nitrogen, $60 \mathrm{~kg}$ Phosphorus and $60 \mathrm{~kg}$ of potash ha ${ }^{-1}$. One third of urea was applied as basal dose during land preparation. The remaining cow dung was applied in split 15 days before seed sowing. The rest of urea was top dressed after each flush of flowering and fruiting in three equal splits. 


\section{Experimental Layout:}

Five cucurbit varieties: cucumber (Cucumis sativus L.), bitter gourd (Momordica charantia L.), ridge gourd (Luffa acutangula (Roxb.) L.), pumpkin (Cucurbita pepo L). and water melon (Citrullus lanatus (Thunb.)), were sown in each pit by hand. A total of 75 marlas of experimental area was prepared. Area was divided into three blocks consisting of 25 marlas each. Each block was further divided into 5 plots. Thus, there were $15(5 \times 3 \mathrm{~m})$ unit plots in the experiment. Two beds were prepared in each unit plot. The size of each bed was $9 \times 3 \mathrm{~m}$. Block to block distance was maintained at 3 meters. Bed to bed distance was maintained $0.4 \mathrm{~m}$ in each unit plot. Plant to plant distance was kept at $0.5 \mathrm{~m}$.

\section{Insect Collection:}

Several surveys of cucurbit fields from different locations in and around the College of Agriculture, University of Sargodha were conducted. Red pumpkin beetles were collected from surrounding fields and transferred to laboratory of Entomology at College of Agriculture, Sargodha for identification and rearing purpose. The beetles were identified on the basis of abdominal tip differences by using entomological keys prior to its further rearing (Rathodi et al., 2009).

\section{Colony Maintenance:}

Colonies of red pumpkin beetle were separately maintained in cages on different cucurbit plants and with $10 \%$ sugar solution under laboratory conditions $\left(25 \pm 2{ }^{\circ} \mathrm{C}, 60-75 \%\right.$ relative humidity). Leaves were replaced regularly and cages were cleaned for any debris and excreta on regular basis. The surface of cage was provided with a thin layer of soil for egg laying. Moisture was maintained in the cages by providing water with the help of plastic shower.

\section{Field Choice Test:}

Ten randomly selected leaves of each cultivar in each block $(10 \times 5 \times 3=150)$ were tagged and counted for RPB populations on weekly basis for a period of three months (15 March to 15 June) for both years (2014-2015). A digital meteorology instrument was used to measure mean average temperature $\left({ }^{\circ} \mathrm{C}\right)$ and relative humidity $(\%)$ for three months on daily basis. The data were taken to record the feeding preference of RPB for the cucurbit cultivars under study.

\section{No Choice Test:}

Five plants from each cultivar were selected in each block. Two plant leaves of each cultivar from each block of appropriate size were caged with muslin cloth. Two plants of each cultivar, specified as control plants, in each block were also covered with field cages. Laboratory reared population of red pumpkin beetle was used for no choice test in the field. Beetles were starved for a day prior to release upon the caged leaves. The leaf area was measured using leaf area meter, portable laser LAM (C1-202; CID Bio-Science) before and after 24, 48, 72 and 96 hours of release of ten red pumpkin beetles. The data were recorded to quantify the amount of leaf area consumed for each cultivar for determination of feeding preference of RPB for the cucurbit cultivars under study.

\section{Statistical Analysis:}

Data were recorded from 15 days after transplanting. Randomized Complete Block Design with 3 blocks was analyzed by using SAS software. ANOVA (analysis of variance) and LSD were applied for estimating the effect of macro and micronutrients on feeding behavior of RPBs. Furthermore, correlation between RPB population and nutritional profile was also analyzed. 


\section{RESULTS}

\section{Field Choice Test:}

Among 5 cucurbit cultivars, bitter gourd had the lowest insect count (30.38/10 leaves) recorded over 12 weeks. All other cultivars showed similar insect countover 12 weeks (Fig.1). However, susceptible cucurbit cultivars such as cucumber (112.67/10 leaves) and pumpkin (112/10 leaves) achieved highest countsat $3^{\text {rd }}$ week of collection. On the other hand, bitter gourd reached the highest count (64.33/10 leaves) at $7^{\text {th }}$ week of infestation but the numbers were lower than all other cucurbits. Cucurbit hosts such as ridge gourd (104.50/10 leaves) and water melon (113.33/10 leaves) achieved the highest count at $6^{\text {th }}$ week of collection (Fig.1).

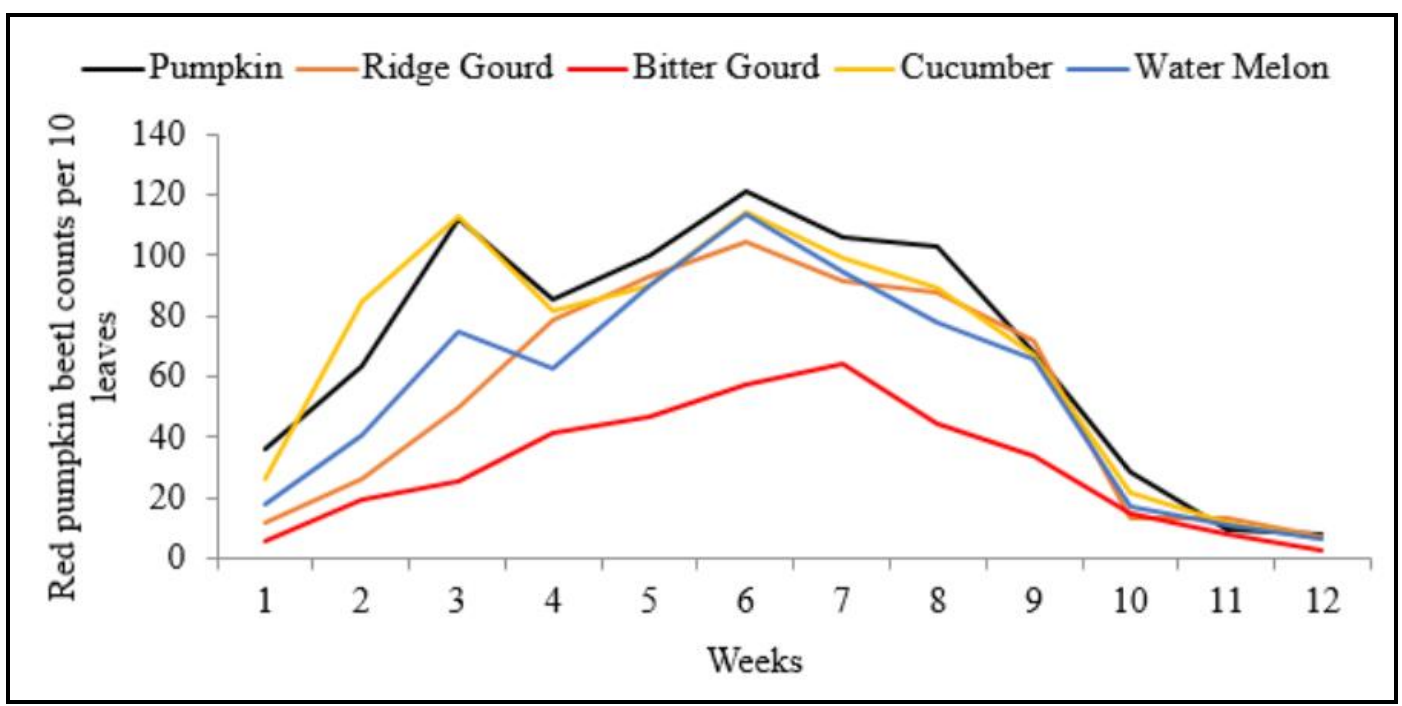

Fig. 1: Relative counts of red pumpkin beetle on various cucurbit cultivars over 12 weeks averaged for both years

In yearly comparison, it was observed that RPB counts increased up to $6^{\text {th }}$ week (96.80/10 leaves and107.20/10 leaves) invariably in 2014 and 2015 followed by a subsequent drop in numbers (Fig. 2). Population count of 2015 was consistently higher than 2014 except at $9^{\text {th }}$ and $10^{\text {th }}$ week of the collection of red pumpkin beetles. Mean values of RPB counts were 97/10 leaves) and 107/10 leaves for 2014 and 2015 (Fig. 2) respectively.

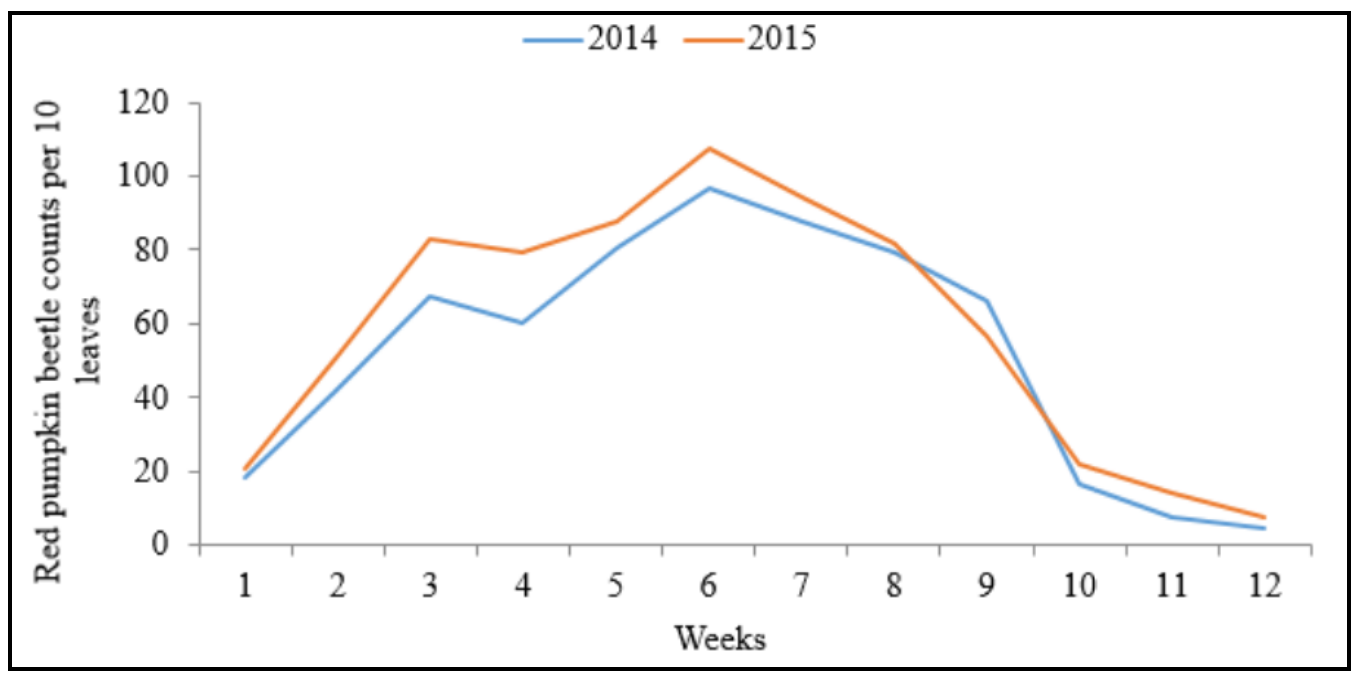

Fig. 2: Red pumpkin beetle counts for years 2014 and 2015 


\section{No Choice Test:}

Continuous decrease in leaf area of various cucurbit cultivars over various time intervals was recorded (Fig. 3). Minimum leaf area reduction was noticed in bitter gourd $(22 \%)$ while the maximum leaf area reduction was observed in pumpkin cultivar (64\%) after 96 hours of red pumpkin beetle infestation (Fig. 3). Other cucurbit cultivars such as cucumber, water melon and ridge gourd showed 55\%, $49 \%$ and $45 \%$ reduction in leaf area after 96 hours respectively.

As per the data, bitter gourd showed tolerance to the beetle infestation, while other cucurbit cultivars like pumpkin and cucumber showed higher susceptibility to the RPB infestation (Fig. 3). Bitter gourd and water melon had minimum leaf area/diameter before releasing the red pumpkin beetles but after 96 hours of infestation, bitter gourd showed lowest reduction in leaf area due to low infestation of red pumpkin beetle (Fig. 3).

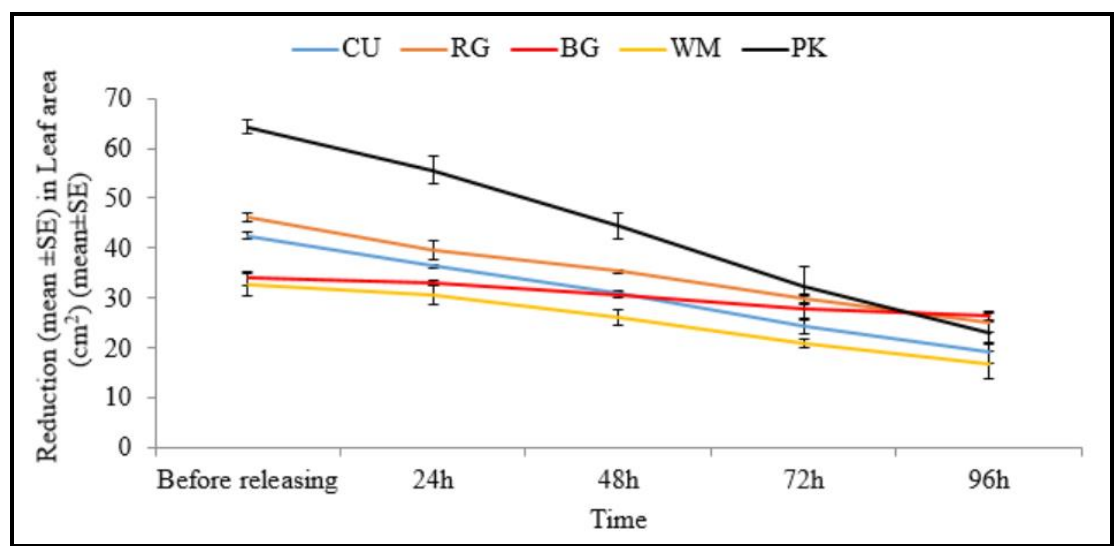

Fig. 3: Leaf area reduction over time intervals (mean \pm SE) of various cucurbit cultivarsdue to red pumpkin beetle infestation

Where cucumber (CU), redge gourd (RG), bitter gourd (BG), water melon (WM)and pumpkin (PK)

The figure 4 shows averaged leaf area of all cultivars. Pumpkin had the highest leaf area before release of insect in both years (2014-2015), but the leaf area was significantly ( $\mathrm{P} \leq$ 0.01) lower during 2014 compared to 2015. Other cucurbit cultivars had similar leaf area in both years beforerelease of insect. Water melon had the lowest leaf area in both years (Fig. 4).

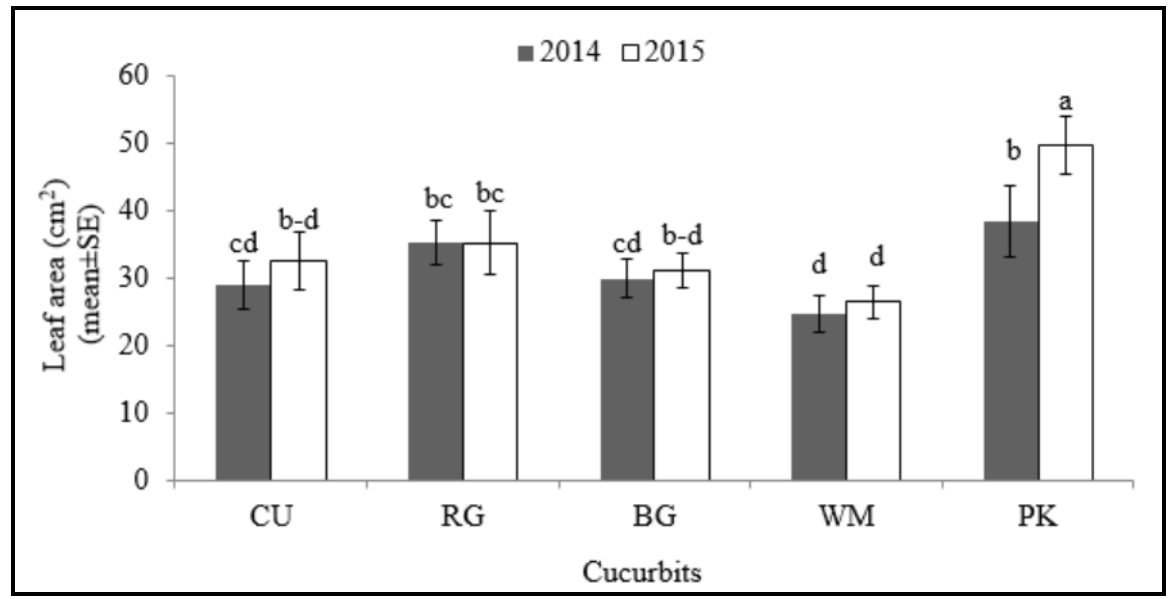

Fig.4: Leaf area of various cucurbit cultivars over tow years (2014-1015) of red pumpkin beetle infestation.

Where cucumber (CU), redge gourd (RG),bitter gourd (BG),water melon (WM)and pumpkin(PK) 


\section{Macro and Micro Analysis of The Nutrient in Cucurbit Cultivars for RPB infestation:}

Nutrient analysis involved determining the values for macro and micronutrients in all cucurbit cultivars. Pumpkin possessed the highest amount of nitrogen $(6.91 \%)$ followed by watermelon and ridge gourd while significantly $(\mathrm{P} \leq 0.05)$ low nitrogen percentage was observed in cucumber and bitter gourd. All cultivars of cucurbits had similar $(\mathrm{P} \geq 0.05)$ phosphorus and potash (\%) except pumpkin which showed significant $(\mathrm{P} \leq 0.05)$. Micronutrient analysis revealed that cucumber was highly enriched with $\mathrm{Zn}(54.16 \pm 3.53 \mathrm{mg}$ $\left.\mathrm{kg}^{-1}\right)$ whereas highest $\mathrm{Cu}$ content $\left(22.57 \pm 3.16 \mathrm{mg} \mathrm{kg}^{-1}\right)$ was present in watermelon among all cultivars. All cucurbits had high Fe values; however, the highest value was recorded for ridge gourd $\left(521.53 \pm 8.5 \mathrm{mgkg}^{-1}\right)$. Bitter gourd was found to be rich in Mn $\left(79.47 \pm 4.6 \mathrm{mg} \mathrm{kg}^{-1}\right)$ compared to other cucurbits (Table 1).

Table 1. Macro \& Micro nutrient analysis of different cucurbits

\begin{tabular}{|c|l|l|l|l|c|c|c||}
\hline \multirow{2}{*}{ Cultivar } & \multicolumn{3}{|c|}{ Macro-nutrient (\%) } & \multicolumn{3}{c||}{ Micro-nutrients (mg kg $\left.{ }^{-1}\right)$} \\
\cline { 2 - 8 } & $\mathrm{N}$ & $\mathrm{P}$ & $\mathrm{K}$ & $\mathrm{Zn}$ & $\mathrm{Cu}$ & $\mathrm{Fe}$ & $\mathrm{Mn}$ \\
\hline Cucumber & $1.75 \pm 0.01^{\mathrm{d}}$ & $0.30 \pm 0.05^{\mathrm{b}}$ & $2.4 \pm 0.18^{\mathrm{b}}$ & $54.16 \pm 3.53^{\mathrm{a}}$ & $18.07 \pm 2.30^{\mathrm{bc}}$ & $419.3 \pm 16.6^{\mathrm{c}}$ & $70.75 \pm 1.69^{\mathrm{b}}$ \\
\hline Ridge Gourd & $2.61 \pm 0.07^{\mathrm{c}}$ & $0.43 \pm 0.01^{\mathrm{b}}$ & $1.8 \pm 0.21^{\mathrm{b}}$ & $40.53 \pm 0.74^{\mathrm{b}}$ & $20.76 \pm .044^{\mathrm{ab}}$ & $521.53 \pm 8.5^{\mathrm{a}}$ & $29.12 \pm 1.43^{\mathrm{d}}$ \\
\hline Bitter Gourd & $2.36 \pm 0.03^{\mathrm{cd}}$ & $0.31 \pm 0.02^{\mathrm{b}}$ & $2.6 \pm 0.01^{\mathrm{b}}$ & $45.35 \pm 1.44^{\mathrm{b}}$ & $19.55 \pm 1.25^{\mathrm{ab}}$ & $294.36 \pm 4.0^{\mathrm{d}}$ & $79.47 \pm 4.60^{\mathrm{a}}$ \\
\hline Water Melon & $6.16 \pm 0.01^{\mathrm{b}}$ & $0.38 \pm 0.04^{\mathrm{b}}$ & $2.1 \pm .023^{\mathrm{b}}$ & $53.57 \pm 3.64^{\mathrm{a}}$ & $22.57 \pm 3.16^{\mathrm{a}}$ & $214.98 \pm 6.1^{\mathrm{e}}$ & $33.94 \pm 2.90^{\mathrm{d}}$ \\
\hline Pumpkin & $6.91 \pm 0.06^{\mathrm{a}}$ & $0.68 \pm 0.05^{\mathrm{a}}$ & $6.6 \pm 0.62^{\mathrm{a}}$ & $41.88 \pm 3.91^{\mathrm{b}}$ & $14.57 \pm 2.22^{\mathrm{c}}$ & $475.1 \pm 19.4^{\mathrm{b}}$ & $45.96 \pm 3.55^{\mathrm{c}}$ \\
\hline
\end{tabular}

$\mathrm{N} \%=$ Nitrogen $\% ; \mathrm{P} \%=$ Phosphorus; $\mathrm{K} \%=$ Potassium; $\mathrm{Zn}=\mathrm{Zinc} ; \mathrm{Cu}=\mathrm{Copper} ; \mathrm{Fe}=\mathrm{Iron} ; \mathrm{Mn}=\mathrm{Manganese}$

Pearson correlations were estimated for RPB infestation and nutritional content of all studied cucurbits. Correlation between red pumpkin beetle infestation and macro elements such as phosphorus and potassium were positive and significant $(\mathrm{P} \leq 0.01)$. On the other hand, micro elements showed both varied relationship with red pumpkin beetle count (Table 2). $\mathrm{Cu}$ exhibited negative but significant $(\mathrm{P} \leq 0.01)$ relation with $\mathrm{RPB}$ infestation rate. Additionally, Fe displayed positive and significant correlation with infestation of RPB. The relation was non-significant $(\mathrm{P} \geq 0.05)$ negative for $\mathrm{RPB}$ counts and other micronutrients $(\mathrm{Zn}$ and $\mathrm{Mn}$ ) alluding to fact that nutritionally rich hosts had higher red pumpkin beetle infestation than other cucurbits.

Table 2. Pearson correlation between the red pumpkin beetle infestation and macro and micro elements

\begin{tabular}{|c|c|c|c|c|c|c|c|}
\hline Traits & RPB & N\% & P\% & K\% & Zn & $\mathbf{C u}$ & Fe \\
\hline $\mathrm{RPB}$ & 1 & & & & & & \\
\hline $\mathrm{N} \%$ & $0.40^{\mathrm{NS}}$ & 1.00 & & & & & \\
\hline $\mathrm{P} \%$ & $0.53^{*}$ & 0.74 & 1.00 & & & & \\
\hline $\mathrm{K} \%$ & $0.46^{*}$ & 0.66 & 0.88 & 1.00 & & & \\
\hline $\mathrm{Zn}\left(\mathrm{mg} \mathrm{kg}^{-1}\right)$ & $0.15^{\mathrm{NS}}$ & -0.08 & -0.59 & -0.40 & 1.00 & & \\
\hline $\mathrm{Cu}\left(\mathrm{mg} \mathrm{kg}^{-1}\right)$ & $-0.47^{*}$ & -0.22 & -0.66 & -0.87 & 0.35 & 1.00 & \\
\hline $\mathrm{Fe}\left(\mathrm{mg} \mathrm{kg}^{-1}\right)$ & $0.46^{*}$ & -0.18 & 0.48 & 0.32 & -0.63 & -0.55 & 1.00 \\
\hline $\mathrm{Mn}\left(\mathrm{mg} \mathrm{kg}^{-1}\right)$ & $-0.38^{\mathrm{NS}}$ & -0.53 & -0.46 & -0.01 & 0.26 & -0.30 & -0.21 \\
\hline
\end{tabular}

*=significant at $\mathrm{p}<0.01 \mathrm{~ns}=$ non-significant $\mathrm{RPB}=$ Red pumpkin beetle; $\mathrm{N}=$ Nitrogen; $\mathrm{P}=$ Phosphorus; $\mathrm{K}=$ Potassium; $\mathrm{Zn}=\mathrm{Zinc} ; \mathrm{Cu}=$ Copper; $\mathrm{Fe}=\mathrm{Iron} ; \mathrm{Mn}=$ Manganese 


\section{DISCUSSION}

Host preferences of Aulacophora foveicollis on various cucurbit cultivars was assessed based on their nutritional content. Results showed that red pumpkin beetle infested all cucurbits however, the population trend was found significantly different among all the cultivars and time intervals (PES, 2016-2017). This may be due to host preference for the RPB and indicated the presence of various resistance mechanisms in cucurbits. For instance, the bitter gourd had the lowest RPB infestation showing that both antixenosis and antibiosis mechanisms were prevailing in the host species (Virendra et al., 2010). Genetic variation within bitter gourd varieties was also observed for antixenosis and resistant genotypes were selected on the basis of the fruit toughness and number of ribs (Nath et al., 2017). A progressive increase in the population density of beetles occurred from first up to fifth week of cropping period (April 25th to May 23rd) (Singh et al, 2000; Khan et al., 2015).

In the present case, heaviest infestation trend among the cucurbit cultivars was pumpkin>cucumber>watermelon>ridge gourd>bitter gourd; an observation quite similar to Khan et al. (2011) where high density of RPB was recorded on cucumber and squash while lowest beetle count was documented for bottle gourd. In another similar study, squash and cucumber sustained highest RPB population and minimum infestation was recorded in bottle and sponge gourd. The population of red pumpkin beetles reaches its peak during the peak cropping season (Rajak et al., 2001).

Current study observations showed that cucurbit cultivars such as cucumber (112.67/10 leaves) and pumpkin (112/10 leaves) achieved highest beetle count at $3^{\text {rd }}$ week of collection (29 $9^{\text {th }}$ march to $5^{\text {th }}$ April. 2014-2015) These results were in conformity with those reported by Saljoqi and Khan (2007) who reported higher number of beetles on squash followed by cucumber. Few studies had also reported higher RPB infestation on muskmelon and cucumber (Rashid et al., 2014).

Plant with nutrient deficiencies becomes vulnerable to pest and microorganism attack (Datnoff et al., 2007). Micro nutrients like copper (Cu), iron (Fe), manganese (Mn) and zinc (Zn) are known as essential plant nutrients. These elements have a peculiar role in plant development and growth. Thus, their deficiencies in plants may cause diseases in plants and reduce the quality. Relationship between the RPB infestation and macro-nutrients such as phosphorous and potassium was significantly positive $(\mathrm{P} \leq 0.05)$ which show that genotypes accumulating higher level of these macro nutrient had excessive plant growth which made them attractive host for RPB infestation. Feeding on the macro nutrient such as Nitrogen also improves the insect performance (Bala et al., 2018).

In our study, the relationship of micro nutrient was significantly $(\mathrm{P} \leq 0.01)$ positive for red pumpkin beetle infestation with iron $(\mathrm{Fe})$ and significant negative relationship with the higher copper $(\mathrm{Cu})$ contents (Di et al., 2016). Higher accumulation of $\mathrm{Cu}$ may increase host resistance against the beetle infestation and could help to suppress the insect infestation. Negative relationship showed that the cultivars with least copper $(\mathrm{Cu})$ content had higher red pumpkin beetle infestation (Table 2). Therefore, presence of higher copper $(\mathrm{Cu})$ element within the host cultivar could be the indicator of lower red pumpkin beetle infestation. Moreover; our results showed that, $(\mathrm{Fe})$ had significant positive relationship with red pumpkin beetle population.

\section{Conclusions}

In our observation, all the cultivars were preferred by RBP except bitter gourd in open choice. In case of no choice, pumpkin was more preferred and water melon was more resistant to RPB followed by the bitter gourd. Phosphorus, potassium and iron was significant and positively correlated with RPB population, however the copper was negatively correlated. Therefore, appropriate control measure may be taken into consideration as per 
susceptibility of the host to reduce RPB infestation. Our studies have shown that bitter gourd has antixenosis or antibiosis properties, therefore, planting bitter gourd as companion crop as borders or in mix cultivation could safely guard other cucurbits.

\section{REFERENCES}

Bala, K.; Sood, A. K.; Pathania, V. S. and Thakur, S. (2018) Effect of plant nutrition in insect pest management: A review. J. Pharmacogn. Phytochem. 7(4): 2737-2742.

Bhaduri, N.; Gupta, D. P. and Rami, S. (1990). Effect of vegetable oils on the ovipositional behavior of Callosobruchus maculatus (Fabricius). In: "Bruchids and legumes" K. Fujii, A.M.R. Gatehouse, C.D. Johnson, R. Mitchel and T. Yoshida (Eds.). Economics, ecology and coevolution. Springer, Dordrecht, Netherlands, pp. 81-84.

Datnoff, L. E. Elmer, W. H. and Huber, D.M. (2007). Mineral nutrition and plant disease. American Phytopathological Society, APS Press, Minnesota, USA.

Dhillon, M. K.; Naresh, J. S.; Singh, R. and Sharma, N. K. (2005) Reaction of different bitter gourd, Momordica charantia L. genotypes to melon fruit fly, Bactrocera cucurbitae (Coquillett). Indian Journal of Plant Protection 33(1): 55-59.

Di, N.; Hladun, K. R, Zhang, K.; Liu, T. X. and Trumble, J. T. (2016) Laboratory bioassays on the impact of cadmium, copper and lead on the development and survival of honeybee, Apis mellifera L. larvae and foragers. Chemosphere. 152: 530-538.

Karim, M.A. (1992). Insect pests of vegetable crops and their management. In: "Vegetable production and marketing. Proceedings, Symposium" K. Lopezand, E. Libas (Eds.). National Review and Workshop, 26-29January 1992, Gazipur, Bangladesh. Publication 92-379. Asian Vegetable Research and Development Center, Shanhua, Tainan, Taiwan, pp. 110-112.

Khan, L.; Shah, M. and Usman, A. (2015) Host Preference of Red Pumpkin Beetle, Aulacophora faveicollis Lucas (Chrysomelidae: Coleoptera) among different Cucurbits. Journal of Entomology and Zooogy. Studies 3(2): 100-104.

Khan, M. M. H.; Alam, M. Z. and Rahman, M. M. (2011) Host preference of red pumpkin beetle in a choice test under net case condition. Bangl. Journal of Zoology 39(2): 231234.

Khan, M. M. H.; Alam, M. Z.; Rahman, M. M.; Miah, M. I. H. and Hossain, M. M. (2012) Influence of weather factors on the incidence and distribution of pumpkin beetle infesting cucurbits. Bang. Journal of Agriculture Research 37(2): 361-367.

Khursheed, S.; Raj, D. and Ganie, N. A. (2013) Population dynamics of red pumpkin beetle on cucumber in mid-hill Himalayas. Journal of Applied Hortculture 15(2):120-123.

Mahmood, T.; Tariq, M. S.; Khokar, K. M. and Hussain, S. I. (2010) Comparative effect of different plant extracts and insecticide application as dust to control the attack of red pumpkin beetle on cucumber. Pakistan Journal of Agricultural Research 23(3-4).

Malik, A. H. Khuroo, A. A. Dar, G. H. and Khan, Z.S. (2011). Ethnomedicinal uses of some plants in the Kashmir Himalaya.Indian journal of traditional knowledge, Vol 10(2)PP 362-366.

Nath, P.; Panday, A. K.; Kumar, A.; Rai, A. B. and Palanivel, H. (2017) Biochemical resistance traits of bitter gourd against fruit fly Bactrocera cucurbitae (Coquillett) infestation. Journal of Agricultural Science 9: 217-225.

Osman, M. S.; Uddin, M. M. and Adnan, S. M. (2013) Assessment of the performance of different botanicals and chemical insecticides in controlling Red pumpkin beetle Aulacophora foveicollis (Lucas). Persian Gulf Crop Protection 2(3): 76-84.

PES, 2016-17. Pakistan Economic Survey,Economic Adviser's Wing, Finance Division, Government of Pakistan, Islamabad http://wwwfinancegovpk/survey_1617html 
Rahaman, M. A.; Prodhan, M. D. H. and Maula, A. K. M. (2008) Effect of botanical and synthetic pesticides in controlling Epilachna beetle and the yield of bitter gourd. International Journal Of Sustainable Crop Production 3(5): 23-26.

Rahman, A. H. (2003) Bottle gourd, Lagenaria siceraria a vegetable for good health. Nat. Product. Radiance. 2(5): 249-250

Rajak, D. C. (2001) Host range and food preference of the red pumpkin beetle, Aulacophora foveicollis Lucas (Chrysomelidae: Coleoptera). Agricultural Science Digest. 21(3): 179-181.

Rashid, M. A.; Khan, M. A.; Arif, M. J. and Javed, N. (2014) Red pumpkin beetle, Aulacophora foveicollis Lucas; a review of host susceptibility and management practices. Academic Journal of Entomology 7(1): 38-54.

Rathodi, S. T.; Borad, P. K. and Bhat, N. A. (2009) Bio-efficacy of neem based and synthetic insecticides against red pumpkin beetle, Aulacophora foveicollis (Lucas) on bottle gourd. Pest Manag. Hortic.Ecosyst. 15(2): 150-154.

Saljoqi A. U. R. and Khan, S. (2007) Relative abundance of the red pumpkin beetle, Aulacophora foveicophora Lucas, on different cucurbitaceous vegetables. Sarhad Journal of Agriculture 23(1): 135.

Singh, S. V.; Alok, M.; Bisen, R. S. and Malik, Y. P. (2000) Host preference of red pumpkin beetle, Aulacophora foveicollis and melon fruit fly, Dacuscucurbitae. Indian Journal of Entomology 62(3): 242-246.

Virendra, S.; Chhillar, B. S. and Ram, S. (2010) Antibiosis and antixenosis mechanisms of resistance in bitter gourd Momordica charantia L. to melon fruit fly, Bactrocera cucurbitae (Coquillett). Research of Crops. 11(1): 99-105.

Vishwakarma, R.; Chand, P. and Ghatak, S. S. (2011) Potential plant extracts and entomopathogenic Fungi against Red pumpkin beetle, Raphidopalpa foveicollis (Lucas). Annals Plant Protection Science 19(1):84-87. 